\title{
TRPV4 wt Allele
}

National Cancer Institute

\section{Source}

National Cancer Institute. TRPV4 wt Allele. NCI Thesaurus. Code C138112.

Human TRPV4 wild-type allele is located in the vicinity of $12 \mathrm{q} 24.11$ and is approximately $50 \mathrm{~kb}$ in length. This allele, which encodes transient receptor potential cation channel subfamily $\mathrm{V}$ member 4 protein, is involved in calcium transport and osmotic pressure regulation. Mutation of the gene is associated with various osmotic, skeletal and neuromuscular disorders. 